\title{
Funktioner og værktøjer til understøttelse af netbaseret kollaborativ læring
}

\author{
Annelise Agertoft \\ Konsulent \\ Konsulentfirmaet Argo \\ annelise@argo.dk \\ http://www.argo.dk
}

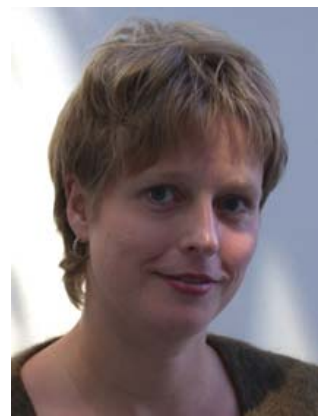

Annelise Agertoft er Cand. Mag. samt Master i IKT \& Loering. Er specialiseret i design, processtøtte, analyser og evalueringer af kompetenceudvikling på arbejdspladsniveau. Centrale erfaringer og interesser er IKT $i$ uddannelser og kompetenceudviklingsprojekter sarligt med henblik på netbaseret kollaboration som en central metode i loereprocesserne. Er endvidere bestyrelsesmedlem i Foreningen for Fleksibel Uddannelse i Danmark, www.fluid.dk.

\section{Indledning}

I det følgende gives ingen anbefalinger af komplette systemer, men der gives anbefalinger til hvilke refleksioner, man bør inddrage forud for sit valg af funktioner og værktøjer til netbaseret kollaborativ læring. Det er min erfaring, at netbaserede kollaborative læringsforløb egner sig til læringsforløb, der i høj grad er baseret på udveksling af erfaringer, synspunkter, argumenter og spørgsmål understøttende kritisk tænkning og refleksion i dialog og diskussion.

Vi lærer, når vi handler, og vi lærer mest, når vi sammen med andre indhenter og i fællesskab bearbejder informationer (Hermansen 1996:64, Wenger 1998). Fordi vi er bærere af forskellige erfaringer, viden, læringsstile og udtryksmåder, kan den måde, hvorpå vi sammen bearbejder informationer sætte gang i individuelle videnkonstruktioner, som vi ikke ellers ville have opbygget. Ikke at vi lærer, bare fordi vi bliver placeret sammen med andre. I et didaktisk perspektiv handler det om at tilrettelægge for at kollaborativ læring kan finde sted. Det gælder både rammefaktorerne, undervisnings- og læringsmål, indhold, arbejdsmetoder samt læringsressourcerne, hvorunder læringsmiljøet hører (Agertoft m.fl. 2003a: 16ff).

Denne artikel tager afsæt i forskningen indenfor CSCL (Computer Supported Collaborative Learning) (Harasim 1990), det vil sige læreprocesser, der tager udgangspunkt i de studerendes fcelles videnskonstruktion (frem for fx underviserstyrede eller individuelle læreprocesser). Videnskonstruktionen er baseret på dialog og gensidig forpligtelse hos de studerende, der arbejder hen mod et fælles mål. IKT anvendes både understøttende og kvalificerende i disse processer. Kollaborativ læring er altså langt mere gensidigt forpligtende end læringsforløb, hvor de studerende på frivillig basis kan kommentere på hinandens (individuelle) opgaver. I kollaborativ læring er samarbejde simpelthen en forudsætning for at læring kan finde sted.

Projektorganiseret læring med udgangspunkt i socialkonstruktivismen er veletableret på en række videregående uddannelser (Dirckinck-Holmfeld 2000). På nogle "on campus" uddannelser anvendes teknologien i dette arbejde, men ofte udelukkende som 
arbejdsredskaber for lagring og udveksling af dokumenter og lignende i projektarbejdet, og den integreres ikke nødvendigvis bevidst som et redskab for kritisk tænkning, dialog og refleksion. I projektorganiserede læreprocesser tilrettelagt som off campus uddannelse er det nødvendigt, at dialogen, den kritiske tænkning og dialogen foregår primært i de netbaserede værktøjer, hvilket afstedkommer særlige kravspecifikationer til funktioner i Elæringssystemet.

Inden for procesorienteret læring arbejdes der off campus i stigende grad desuden med netbaserede plenumdiskussioner, der ligeledes tager udgangspunkt i de studerendes fælles videnskonstruktion, men som til forskel fra den projektorganiserede læring ikke nødvendigvis har en samlet fremstilling som mål. Det er i øvrigt forfatterens påstand, at disse erfaringer fra off campus uddannelser udmærket kan være en inspiration for uddannelser tilrettelagt on campus. I netbaserede plenumdiskussioner synes det at være en særlig vanskelig udfordring at fastholde deltagernes gensidige vidensopbygning som det centrale element bl.a. i og med, at der ikke er et egentligt produktkrav. Anvendelsen af en deltagercentreret didaktik, pensumkrav, evalueringskriterier og netbaserede værktøjer kan medvirke til at fastholde, understøtte og kvalificere den fælles vidensopbygning (Agertoft \& Lerche Nielsen 2003).

Denne artikel videregiver konkrete forslag til overvejelser vedrørende funktioner og eværktøjer, der i særlig grad kan understøtte netbaseret undervisning - både projektorganiseret undervisning og plenumdiskussioner. Forslagene er bl.a. baseret på forfatterens egne erfaringer med at deltage i CSCL som studerende ved $\mathrm{MIL}^{1}$, fra egne erfaringer som facilitator af tværinstitutionelle netbaserede kollaborative læreprocesser i ikke-formelle uddannelser, som ekstern konsulent og som facilitator af intern videndeling. Forfatteren har desuden selv evalueret en række systemer for deres egnethed til netbaseret kollaborativ læring. Visse af disse fremhæves i det følgende for deres enkelte funktioner.

\section{Funktioner og værktøjer til netbaseret kollaborativ læring}

Hvis ellers der didaktisk i selve læringsforløbet tilrettelægges bevidst for kollaborativ læring, vil mange studerende finde vellykkede måder at samarbejde på i systemet, også selv om Elæringssystemet ikke er optimalt i forhold til de didaktiske intentioner. Men der findes Elæringssystemer, der grundlæggende tager udgangspunkt i et læringssyn, der er så langt fra kollaborativ læring, at de vil udgøre en uacceptabel stor hæmsko for at samarbejdende aktiviteter kan finde sted på de studerendes initiativ. Ethvert E-læringssystem tager bevidst eller ubevidst udgangspunkt i et bestemt læringssyn. I mange tilfælde kan det ud fra en rent læringsmæssigt perspektiv svare sig at undersøge systemer, der har haft medarbejdes videndeling som deres mål, fordi disse systemer typisk er mere optagede af forskellige metoder til videndeling i højere grad end af fx kontrol og tests. Med udgangspunkt i det kollaborative arbejdes aktiviteter fremlægges en række forslag til funktioner og værktøjer, der kan virke understøttende og kvalificerende på processen i kombinerede forløb af tilstedeværelsesundervisning og virtuelle perioder. I denne artikel medinddrages ikke forhold omkring administration af kursister, tests, uddannelsesplanlægning etc., idet der fokuseres på de studerendes aktiviteter i gruppen og på holdet.

I virkeligheden vil det i praksis sandsynligvis være nødvendigt at prioritere, hvilke aktiviteter i det kollaborative arbejde, der skal have bedst mulig teknologisk understøttelse, simpelthen fordi E-læringssystemet, der kan det hele, ikke findes.

\footnotetext{
${ }^{1}$ Master i IKT og læring: http://www.hum.auc.dk/mil/
} 


\section{Anbefalinger til overvejelser omkring kravspecifikationer}

I kollaborativ læring skaber de studerende viden ved at meningsforhandle om fortolkninger og handlinger (Wenger 1998, Agertoft m.fl. 2003a: 49ff). Læringsmiljøet skal stille faciliteter til rådighed, der faktisk kvalificerer den meningsforhandling.

Fire centrale aktiviteter for netbaserede kollaborative grupper af studerende er produktion af viden, beslutningstagning, praktisk koordination og opretholdelsen af fællesskabet.

Forskellige funktioner og værktøjer understøtter dem (figur 1). En række af disse gennemgås i det følgende. ${ }^{2}$

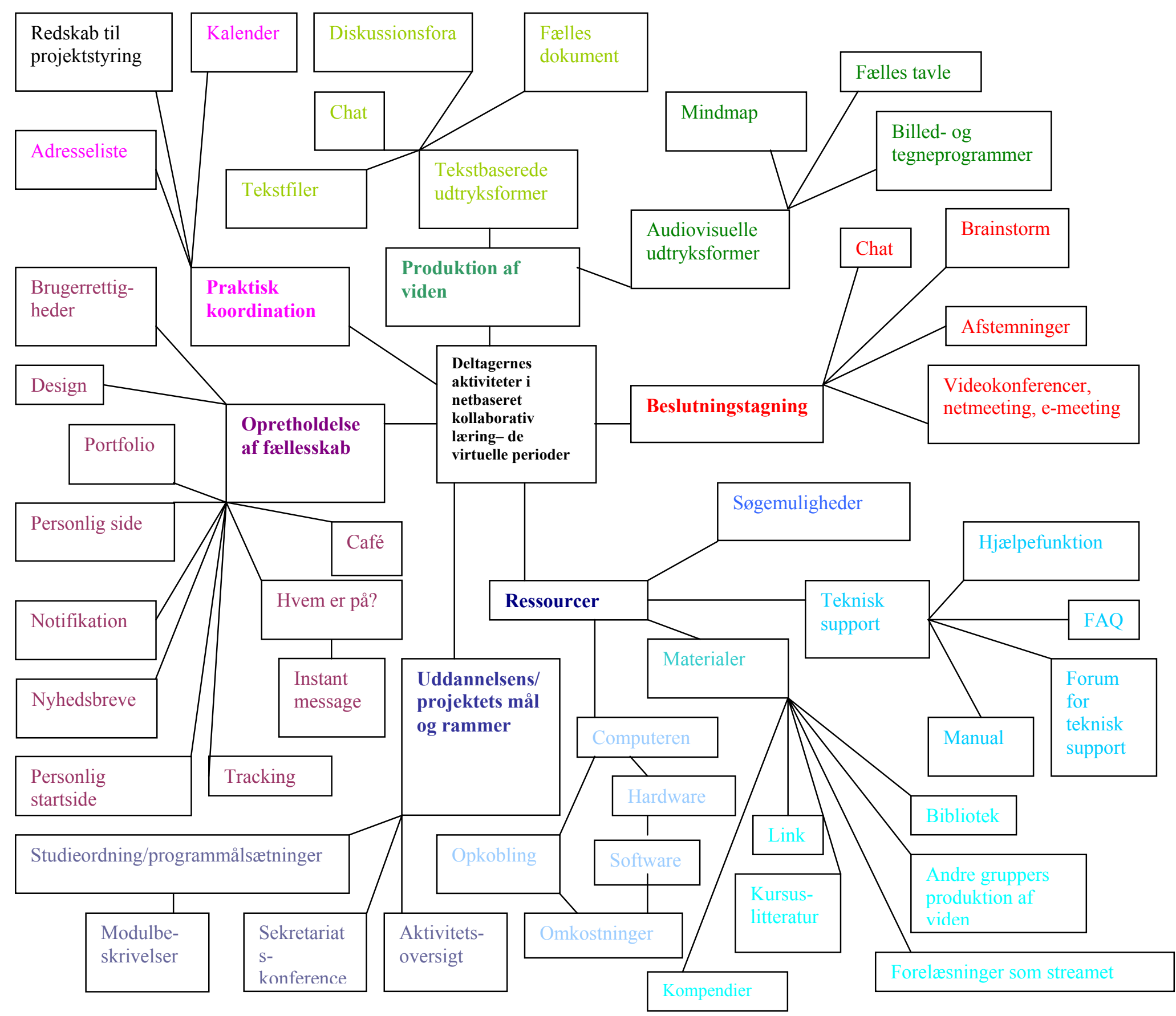

Figur 1. visualiseringsmodel udarbejdet af A. Agertoft, copyright Billesø \& Baltzer 2003.

\footnotetext{
${ }^{2}$ For en grundigere gennemgang, der også inkluderer uddannelsens rammer og ressourcer, henvises til Agertoft m.fl. 2003a
} 


\section{Produktion af viden}

Den kollaborative gruppe har som mål at producere noget. I det projektorienterede forløb kan det være en skriftlig opgave, en cd-rom eller noget helt andet. I et procesorienteret forløb kan det være diskussion af temaer eller udveksling af erfaringer. Den første type forløb findes ikke uden elementer af den anden. Under alle omstændigheder har deltagerne brug for redskaber til at lette arbejdet med fremstillingsformerne, som $\mathrm{fx}$ asynkrone diskussionsfora til diskussion og refleksion. I den forbindelse bør man overveje at give deltagerne mulighed for følgende værktøjer og funktioner:

\section{Diskussionsfora}

Diskussionsforaene skal kunne indrettes, sådan at deres struktur tilpasses løbende i forhold til udviklingen i kommunikationen, og det er afgørende, at deltagerne selv har rettigheder til at oprette fora. Det er desuden af stor betydning, at der er gode muligheder for udskrift af tråde. Denne funktion gør det det også muligt at anvende plenumdiskussionen som materiale for en evaluering.

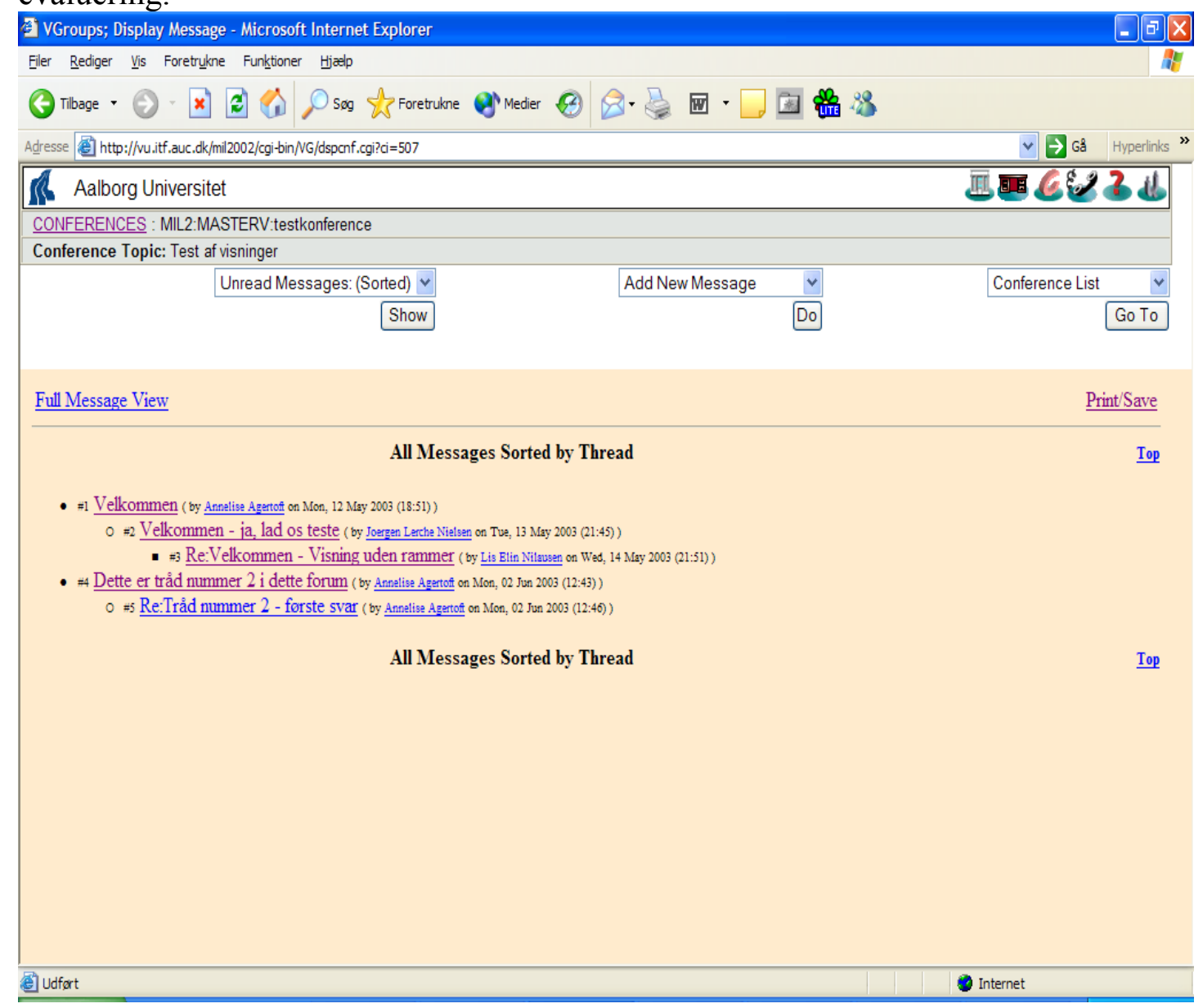

Figur 2. Det virtuelle loeringsmiljø Virtual-U; visning af tråde.

- Diskussionsforaene skal give mulighed for at følge én dialog og én tråd - altså et emne pr. tråd (figur 2)

- Der bør være en oversigtsside med alle tråde (én fortløbende side)

- Mulighed for visning og udskrift af hel tråd i fortløbende tekst (Virtual-U har visning efter forfatter, dato, læst, ulæst, omvendt dato mv.) (figur 3)

- Ubegrænset antal niveauer i tråde

- (Valgfri) citatfunktion

- Mulighed for formateret tekst $\mathrm{i}$ indlæg, fordi det fremmer overblik, når flere citeres $\mathrm{i}$ samme indlæg 
- Man skal som deltager kunne ændre på emnetitlen, når man anvender svarfunktion

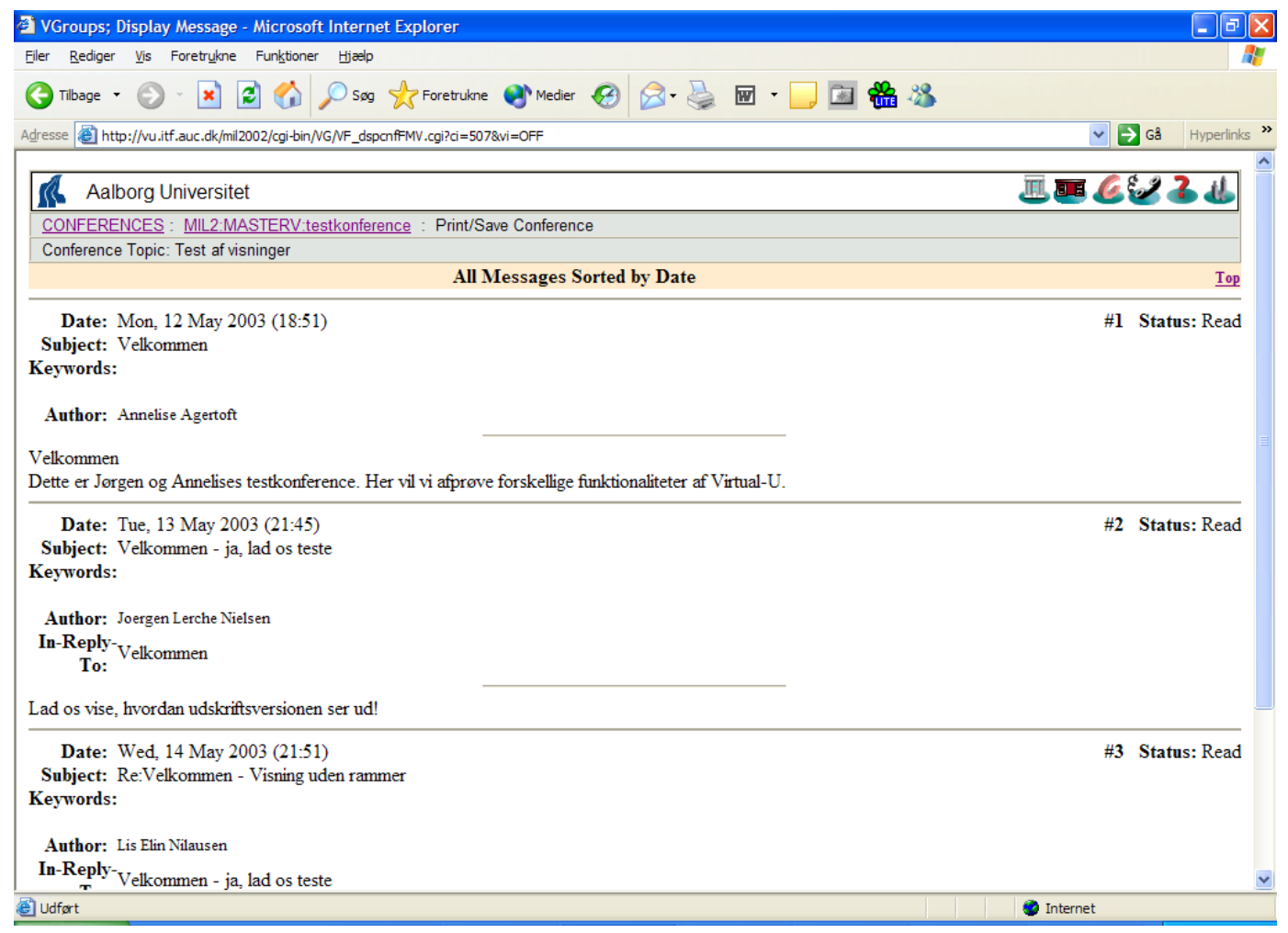

Figur 3. Det virtuelle loeringsmiljø Virtual-U; udskriftsvisning af tråde.

\section{Projektarbejde}

For projektgruppen er det afgørende, at den selv har rettighed til at oprette en struktur, der svarer til den måde, gruppen forstår og dermed ønsker at systematisere sine dokumenter. Jo mere fællesskab der er i gruppen omkring dens mål og måder at nå dem, jo snævrere vil samarbejdet i gruppen være, og sandsynligvis vil der opstå situationer, hvor man skriver videre og justerer i andres tekster. Hvis gruppen har en vis størrelse, kan dette give uoverskuelige versioner, hvorfor det er værd at overveje funktioner, der understøtter den tætte kollaboration i udarbejdelsen af dokumenter, såsom versionsstyring og fælles dokument (synkront samarbejde i samme dokument).

- Grupperettigheder til oprettelse af diskussionsfora

- Grupperettigheder til oprettelse af fildelingsrum

- Versionsstyring, fælles dokument (BSCW, Netstudier, Fronter)

- Alle typer og versioner af filer skal kunne uploades (af de studerende selv)

- Synkron fælles tavle ved geografisk adskillelse

\section{Beslutningstagning}

Jo større den virtuelle projektgruppe er, og jo mere den producerer, jo større er dens behov for redskaber til at træffe beslutninger. Forhandlinger i det non-verbale virtuelle rum er særligt vanskelige. Det kan nogle gange være vanskeligt at afgøre, hvilke beslutninger, der skal vælges imellem (fx hvilke problemformuleringer), og den synkrone dialog er ikke dynamisk og effektiv nok, når der skal handles hurtigt (Dirckinck-Holmfeld, Tolsby \& Nyvang 2002). Her understøtter fx chat den hurtige udveksling og koordination af holdninger. Audio-visuel synkron kommunikation kan ydermere være en vej uden om mange potentielle misforståelser, men de kræver en kapacitet og et udstyr, som vi endnu ikke kan regne med er standardudstyr hos studerende og undervisere. 
- Afstemningsredskab (Netstudier) (figur 4)

- Chat med funktioner som:

○ hvem er i chatten, når man går ind

○ hvem er i gang med at skrive et indlæg

○ farvekodning e. lign.

○ mulighed for at lagre på disk

- gratis på nettet (ICQ, MSN Messenger)

- Web cam i netmeeting (lyd, billede) (MSN NetMeeting, Yahoo Messenger)

- E-meeting (lyd, billede, tegneredskaber, follow-me) (VoiceCafé Classmaster, Marratech)

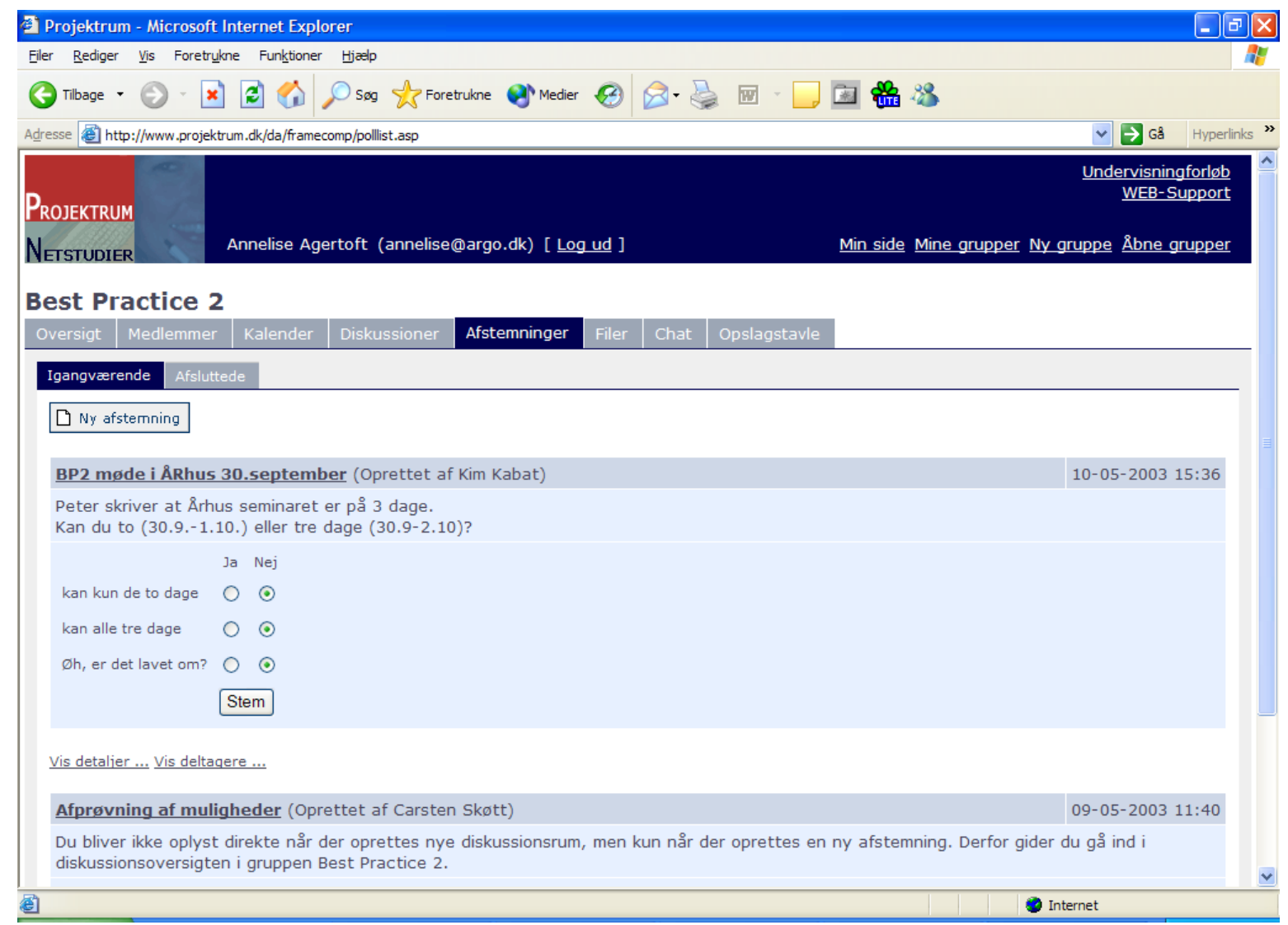

Figur 4. Det virtuelle loeringsmiljø Netstudier; Afstemning.

\section{Praktisk koordination}

Særligt i omfattende projekter (gruppestørrelse/tid/omfang) er der behov for koordination af handlinger. Dette forgår mest effektivt i fysiske møder, men i en situation, hvor fysiske møder kun finder sted sjældent, kan det være vanskeligt at bevare overblikket over, hvem der gør hvad, hvornår. Der findes projektstyringsredskaber, der faciliterer koordinationen og fremmer det visuelle overblik.

- Fælles kalender (ikke kun platform for læreren, men de studerendes redskab) (Netstudier)

- Flow diagram (til visning af tidssammenhænge mellem aktiviteter) (QuickPlace) (figur 5) 


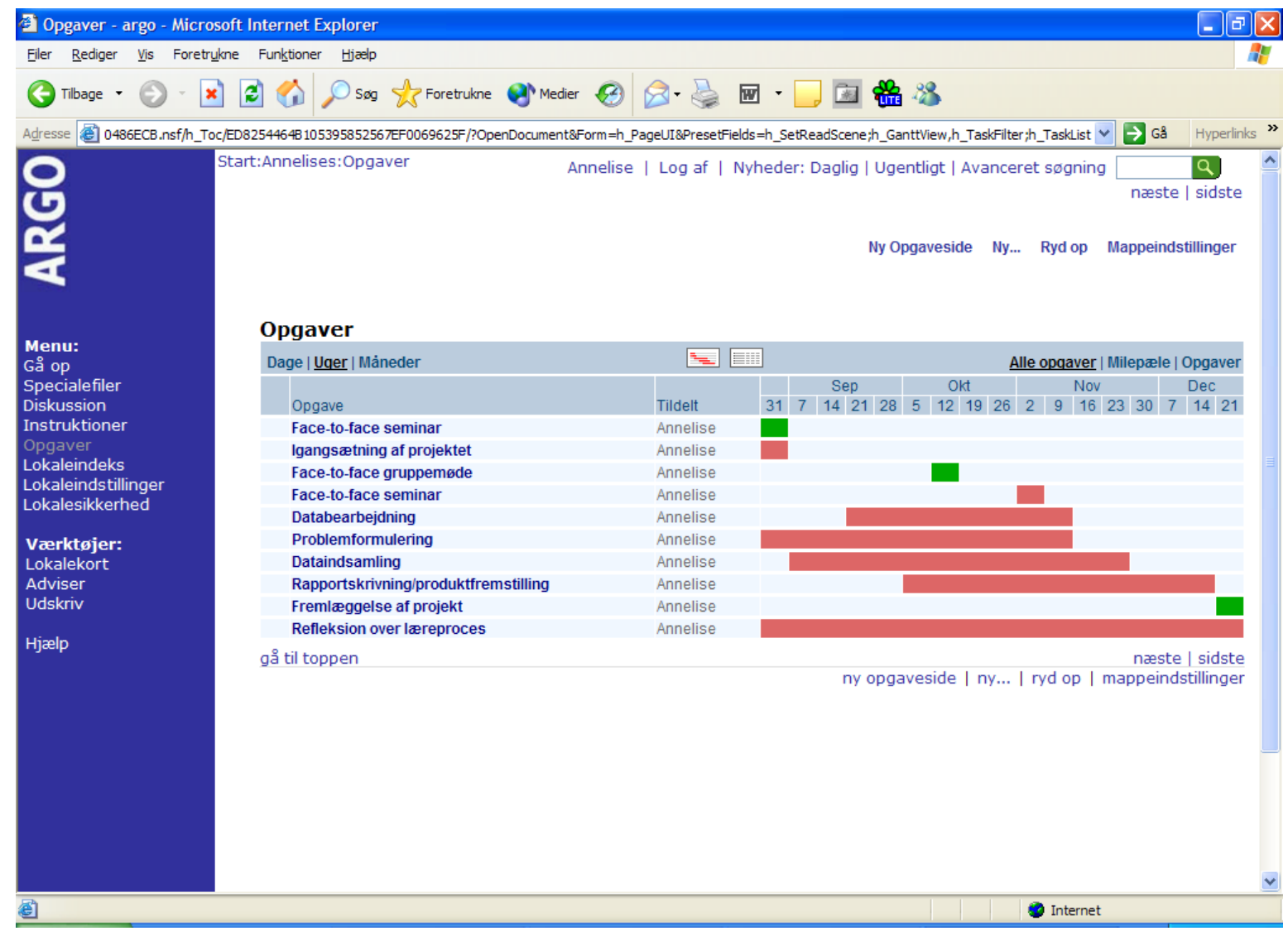

Figur 5. Samarbejdssystemet QuickPlace, flow diagram.

\section{Opretholdelse af fællesskabet}

Et særligt problem i virtuelle grupper er skabelsen af og fastholdelsen af gensidigt engagement (Wenger 1998). Det er af stor betydning i det kollaborative arbejde, at alle deltagere betragter sig som del af et praksisfællesskab og at de føler den gensidige afhængighed og dermed forpligtelse. Den indledende skabelse af engagementet i gruppen kan vanskeligt finde sted på anden måde end ved fysiske møder, og det fastholdes og udvikles bedst ved vekslen imellem fysiske og virtuelle møder. Fastholdelsen kan virtuelt understøttes ved forskellige værktøjer og funktioner, der fremmer følelse af tilstedeværelse, fællesskab og "synlighed".

- Instant message (gør det muligt at identificere, hvem der er online og sende dem en besked)

- Notifikation (abonnement på bevægelser i (dele af) læringssystemet)

- Visning af sidste nyt (se figur 6) 


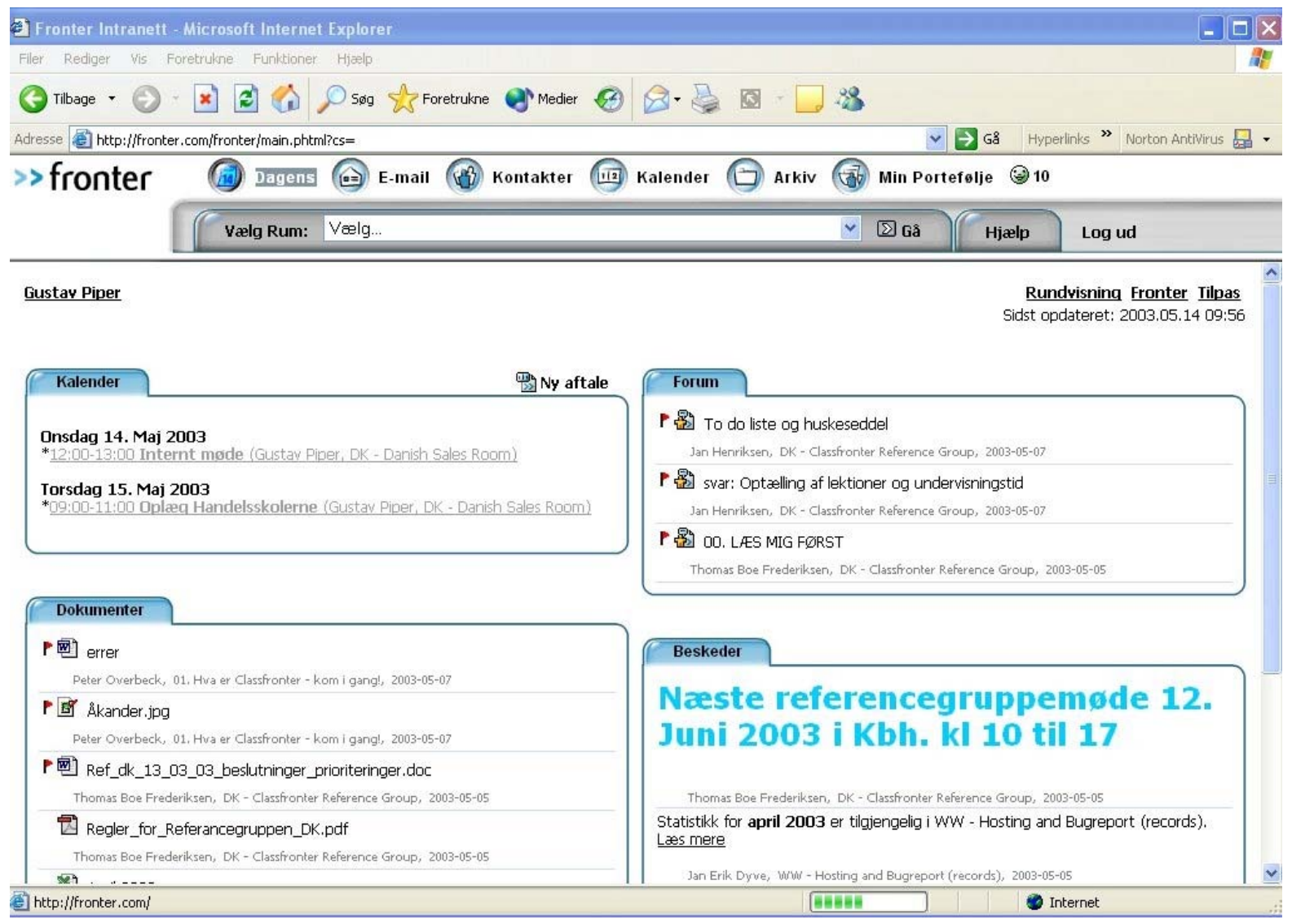

Figur 6. Det virtuelle laeringsmiljø Fronter; startside med visning af sidste nyt ved flag.

Samarbejde kræver kendskab til gensidige kompetencer. På de indledende fysiske møder vil der givetvis foregå en præsentationsrunde, men dels vil den af ressourcemæssige årsager være overfladisk, dels vil den typisk ikke være lagret. Det bør derfor overvejes, at deltagerne har mulighed for at lagre, justere og frekventere præsentationer i systemet. Som et supplement eller som en integreret del af de personlige præsentationer, kan de studerende arbejde med at definere egen rolle og målsætninger i arbejdet ved at lagre og reflektere over egne handlinger, produkter og erfaringer på et metaniveau. Som et af de nye, interessante og fleksible redskaber til dette kan man overveje weblogs.

- Personlige præsentationssider

- Virtuel portfolio

- Weblog (http://new.blogger.com/)

Tekstbaseret dialog mangler markører af, hvem der "hører efter". Intet er så frustrerende som at have afleveret et indlæg, og ingen reagerer med et andet indlæg. Men hvis man i det mindste ved, at indlægget er blevet åbnet af de andre deltagere, kan man bedre holde ventetiden ud, og man føler stadig at man er en del af en gruppe. Nogle systemer har en funktion, som giver mulighed for at se, hvem der har åbnet hvilke indlæg. Det er dog vigtigt, at systemet ikke kun giver administrator eller underviserne denne rettighed.

- Tracking

Systemer, værktøjer og funktioner der dels er brugervenlige, dels giver de studerende rettigheder på intruktørniveau vil potentielt kunne fremme deltagernes fornemmelse af ejerskab og engagement på en anden måde end meget begrænsede brugerrettigheder vil. Her kan man også gøre sig overvejelser over brugerrettigheder i forhold til grafisk design af gruppens egne rum. 


\section{Sammenligning af systemer}

Indtil det bliver håndterbart at sammenstykke sit eget system af diverse værktøjer fra fx Open Source, kan det være nødvendigt at gå på kompromis og prioritere de aktiviteter, de studerende skal arbejde med og de deraf følgende funktioner og værktøjer. På den baggrund kan man evt. vælge et eksisterende system i sin helhed. For så vidt, man vil prioritere kollaborativ læring, kan man bl.a. tage udgangspunkt i de her nævnte parametre, når man udarbejder sine kravspecifikationer, alternativt findes en række websites, som sammenligner systemer. Nogle af dem er endda interaktive. Men generelt lider de under det problem, at de ikke tager udgangspunkt i et læringssyn, men i teknologiske kravspecifikationer, og ofte også kun har en lille detaljeringsgrad, hvad angår funktionsbeskrivelser. Der er en klar tendens til at tage udgangspunkt udelukkende i tekniske specifikationer og administrative funktioner frem for også eksplicitte didaktiske målsætninger. Et eksempel på et interaktivt website, hvor man selv kan sætte de (faste variable) parametre er www.edutools.info. Der findes desuden en schweizisk evalueringsside under Swiss Virtual Campus, hvis formål er at sprede anvendelsen af IKT i videregående uddannelser; http://www.edutech.ch/edutech/tools/ev2.php. Deres evalueringskriterier er stort set udelukkende tekniske. Britain og Liber fra University of Wales - Bangor har skrevet en artikel, hvori de medtager en lang række parametre, som kan inspirere til formulering af kravspecifikationer, og de har ligeledes analyseret en række engelsksprogede systemer på baggrund af deres parametre som to sæt af evalueringsparametre (http://www.leeds.ac.uk/educol/documents/00001237.htm\# Toc463843839). Her tages udgangspunkt i pædagogikken, men desværre en gennemgangen ikke detaljeret nok. De nævnte websites for evaluering af systemer kan i en dansk kontekst typisk primært bruges som inspiration for udvikling af egne evalueringskriterier. Når først man som institution selv har formuleret didaktiske og pædagogiske målsætninger og omformuleret dem til krav til funktioner og værktøjer, vil man efterfølgende kunne sammenligne med systemer på disse sites og andres steder.

\section{Afrunding og konklusion}

Dette var i oversigtsform en række af de funktioner og værktøjer, der kan understøtte et didaktisk mål om kollaborativ læring tilrettelagt som en vekslen imellem fysiske og primært virtuelle aktiviteter. Overordnet handler det didaktisk om at understøtte gruppens overordnede opgave med gensidigt og som gruppe selvstændigt at forhandle om fortolkninger og handlinger i de nævnte fire centrale aktiviteter, som er produktion af viden, beslutningstagning, praktisk koordination og opretholdelsen af fællesskabet. Det anbefales især at gøre sig overvejelser over de reelle muligheder for udfoldelse af dialog og diskussioner i diskussionsforaene (fx struktur og visningsformer) og fildelingsrummenes funktioner (fx hierarki og versionsstyring), der understøtter disse. Ligeledes anbefales det at overveje funktioner, der understøtter beslutningstagning (fx synkront som chat eller asynkrone afstemningsredskaber). Arbejdsdelingen i gruppen og overblikket over gruppens samlede aktiviteter befordres af fælles kalender og flow diagram. Sidst, men på ingen måde mindst, er det helt afgørende at finde metoder og dermed funktioner til at fællesskabet kan bæres af forpligtelse, følelsen af virtuel tilstedeværelse og kendskab til hinandens profiler ( $\mathrm{fx}$ notifikation, instant message og personlige præsentationsider).

Uanset hvilket system, funktioner og værktøjer man anvender og uanset deres egnethed for kollaborative læreprocesser, yder de i sig selv ingen garanti for, at der faktisk finder kollaboration og fælles vidensopbygning sted. Dette afhænger af deltagernes motivation og mulighed for at samarbejde, som igen i væsentlig udstrækning afhænger af den didaktiske tilrettelæggelse af læringsforløbet og undervisernes kompetencer som facilitatorer af netbaseret kollaborativ læring. Didaktikken er altså bestemmende for læringsforløbets succes. 
Teknologien kan modarbejde eller understøtte didaktikken, men den kan ikke kompensere for en manglende didaktisk tilrettelæggelse og pædagogisk god praksis.

\section{Litteratur}

Agertoft, A \& I. Bjørnshave \& J. Lerche Nielsen \& L. Nilausen (2003a). Netbaseret kollaborativ loering - en guide til undervisere. Værløse: Billesø \& Baltzer, 2003.

Agertoft, A. \& I. Bjørnshave \& J. Lerche Nielsen \& L. Nilausen (2003b). Deltager $i$ netbaseret loering - en guide til samarbejde. Værløse: Billesø \& Baltzer, 2003.

Agertoft, A \& J, Lerche Nielsen. Undervisning gennem plenumdiskussioner på nettet. Tidsskrift for Universiteternes efter- og videreuddannelse 1.1 (2003). Online: http://www.unev.dk/view.aspx?artikel_id=266 (downloaded 20.01.04).

Britain S. \& O. Liber: A Framework for Pedagogical Evaluation of Virtual Learning Environments. Online:

http://www.leeds.ac.uk/educol/documents/00001237.htm\# Toc463843839 (downloaded 20.01.04).

Dirckinck-Holmfeld, L.Virtuelle læringsmiljøer på et projektpædagogisk grundlag. In: . At undervise med IKT. Ed. S. Heilesen. Frederiksberg: Samfundslitteratur. 2000.

Dirckinck-Holmfeld, L. \& H. Tolsby \& T. Nyvang. E-læringssystemer i arbejdspladsrelateret projektpædagogik. In: Udspil om loering $i$ arbejdslivet. Ed. K. Illeris. Learning Lab Denmark, Frederiksberg C: Roskilde Universitetsforlag/Samfundslitteratur. 2002.

Hermansen M. Loeringens univers. Århus: Forlaget Klim. 1996.

Wenger, E. Communities of Practice. Learning, Meaning and Identity. New York: Cambridge University Press. 1998.

Wenger, E. Supporting Communities of practice - a survey of community oriented technologies. 2001. Online: http://www.ewenger.com (downloaded 20.01.04).

\section{Links}

Konsulentfirmaet ARGO www.argo.dk, annelise@,argo.dk

Foreningen for Fleksibel Uddannelse i Danmark afholder jævnligt konferencer, hvor forskere og praktikere udveksler erfaringer om værktøjer til E-læring. www.fluid.dk

Liste med links til diverse E-læringssystemer; UNESCO free software portal http://www.unesco.org/webworld/portal freesoft/Software/Courseware Tools/

Nævnte E-læringssystemer og værktøjer:

BSCW: http://bscw.gmd.de/

Fronter: http://fronter.info

Netstudier: $\underline{w w w . n e t s t u d i e r . d k}$ 
Tidsskrift for Universiteternes efter- og videreuddannelse (ISSN 1603-5518). 1. årgang, nr. 2, 2004

QuickPlace: www-5.ibm.com/services/learning/dk/it/lotus/

Virtual-U: www.vlei.com

ICQ: http://web.icq.com/

Interwise http://www.interwise.com/

MSN Messenger: http://messenger.microsoft.com/da/

VoiceCafé Classmaster: www.cyberling.dk/telelearning_slides1.html

Marratech: www.marratech.com

NetMeeting: http://www.microsoft.com/windows/netmeeting/

Yahoo Messenger: http://dk.messenger.yahoo.com/

Weblog http://new.blogger.com/ 